yol $\quad 19920$

A-H[erbert]

594 Quall 1850

Henn Hilliam Herbert 1850. Qunit and quail shoting. 


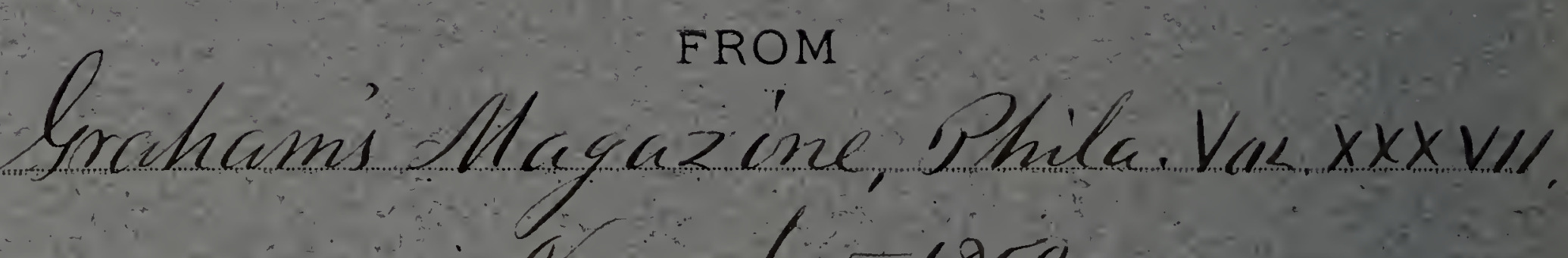
ivountiex 1850 . 


\section{QUAIL AND QUAIL SHOOTING.}

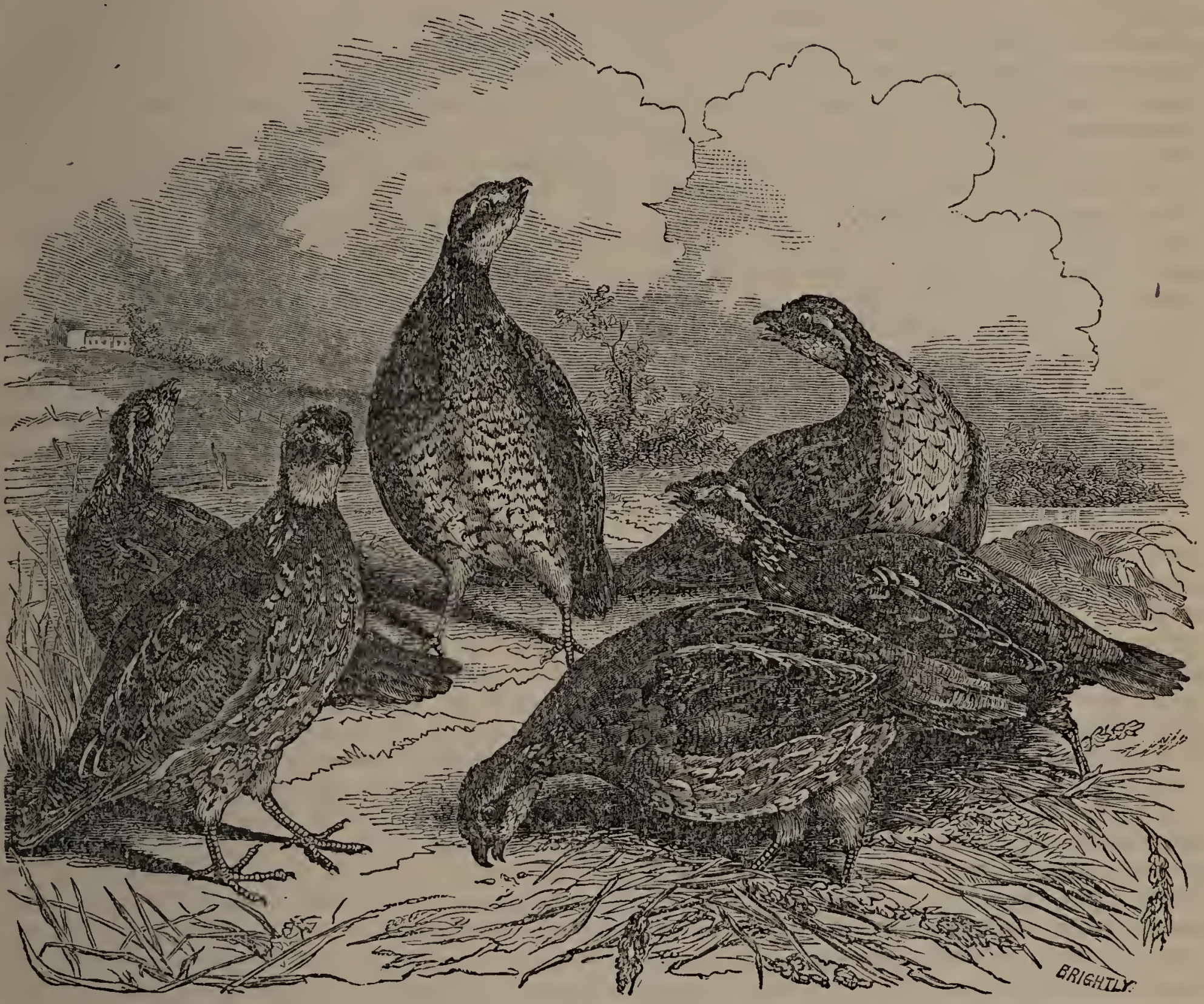

THE AMERICAN QUAIL, OR VIRGINIA PARTRIDGE.

(Ortyx Virginianus. Perdix Virginianus.)

Novimber is upon us-liearty, brown, healthful November, harbinger of his best joys to the ardent sportsman, and best beloved to hin of all the months of the great annual cycle; November, with its clear, braeing, western breezes; its sun, less burning, but how far more beautiful than that of fieree July, as tempered now and softened by the rieh, golden haze of Indian summer, quenching his torrent rays in its mellow, liquid lustre, and robing the distant hills with wreatlıs of purple light, half mist, half shrouded sunshine; November, with its wheat and buckwheat stubbles, golden or bloody red; with its sere mize leaves rustling in the breeze, whence the quail pipes incessant; with its gay woodlands flaunting in their manycolored garb of glory; with its waters more clearly calm, more brilliantly transparent than those of any other scason; November, when the farmer's toils have rendered their reward, and his reaped harvests glut his teeming garners, so that lie too, like the pent denizen of swarming eities, may take his leisure with his gun "in the wide vale, or by the deep wood-side," and enjoy the rapture of those sylvan sports whieh he may not participate in sweltering July, in whieh they are, alis ! permitted by ill-eonsidered legislation, ill every other state, save thine, honest and honorable Massaehusetts.**

In truth there is no period of the whole year so well adapted, botl by the seasonable climate, and the state of the country, shorn of its crops, and not now to be injured by the sportsinun's steady stride, or the gallop of his highbred setters, both by the abundance of gane in the eleared stubbles and the sere woodlinds, and by the aptitude of the brisk, braeing weather for the endurance of fatigue, and the enjoyment of manful exereise, as this our favorite November.

* A law was passed, during the spring of the present year, in that respeetable and truly conservative State, by which the murder of unfledged July Wondeoek, by cockney gumners was prohibited; and the elose time judiciously prolonged until September. The debate was remarkible for two things, the original genius with which the Hon. Member for Westboro' persisted that Snipe are Woodcoek, and Wondeock Snipe, all naturalists to the contriury notwitlstanding; and the pertinent reply to the complaint of a eity member, that to abolish July shooting would rob the city sportsman of his sport-viz., that in that case it would give it to the farmer. Marry, say we, amen, so be it! 
In this month, the beautifnl Ruffed Grouse, that mountain-loving, and man-shuuning hermit, steals down from his wild haunts among the giant rhodollendrons, and evergreen roek-ealmias, to nearer woodskirts, and cedur-brakes margining the red buckwheat stubbles, to be found there by the stauneh dogs, and brought to bag by the quick death-shot, "at morn and dewy eve," without the toil and torture, often most vain and vapicl, of sealing miles on miles of mountain-ledges, struggling through thickets of impenetrable verdure among the close-set stems of hemlock, pine, or juniper, only to hear the startled rush of an unseen pinion, and to pause, breathless, panting, and outdone, to curse, while you gather breath for a renewed effort, the bird whieh haunts such covert, and the covert which gives shelter to such birds.

In this month, if no untimely frost, or envious snow flury come, premature, to ehase him to the sunny swamps of Carolina and the rice-fields of Georgia, the plunı, whitefronted, nink-legged autumn Woodcock, flaps up from the alder-brake with his shrill whistle, and soars away, away, on a swift and powerful wing above the russet tree-tops, to be arrested only by the instinctive eye and rapid finger of the genuine sportsman; and no longer as in faint July to be bullied and bungled to death by every German city pothunter, or every pottering rustic school-boy, equipped and primed for murder, on his Saturday's hạlf holyday.

In this month, the brown-jacketed American hare, which our folk will persist in calling Rabbit-though it neither lives in warrens, nor burrows habitua!ly under ground, and though it breeds not every month in the year, which are the true distinetive characteristics of the Rabbit-is in his prime of conditions, the leverets of the season, plump and well grown; and the old bueks and does, recruited after the breeling season, in high health and strength, and now legitimate food for gunpowder, legitimate quarry for the ehase of the merry beagles.

In this month especially, the Quail, the best-loved and choieest object of the true sportsman's ambition; the bird which alone affords more brilliant and exciting sport than all the rest beside; the bravest on the wing; and the best on the board; the swiftest and strongest flyer of any feathered game; the most baffling to find, the most troublesome to follow up, and when followed up and found, the most difficult to kill in style; the beautiful Ameriean Quail is in his highest forcc and feather; and in this month, according to the laws of all the States, even the most rigorous and stringent in preservation, killable legitimately uncler statute.

In New York, generally, the close-time for the Qnail ends with October, and he may not be slain until the first day of November; in New Jersey, ortygicide commences on the 25th of Oetober, in Massaelusetts and Connecticut on some day between the 15th of the past and the first of the present montl ; in Pennsylvania, Delaware and Maryland, where they are something more forward, as breeding earlier in the season than in the Eastern States, on the first of October; and in Canada WVest, where they are exceedingly abundant, on the first of September; which is, for many reasons, entirely too early, as hereafter I shall endeavor to demonstrate.

In my own opinion, the first of November, and even the middle of October, are too late for the termination of the Quail's close-time, inasmuch as five-sevenths of the broods in ordinarily forward seasons are full-grown and strong on the wing, as well as all the crops off the ground, by the first of October; and although the late, seeond, or third broods may be undersized, they are still well able to take care of themselves in case the parent birds are killed; whereas, on account of their immature size, they are safe irom the legitimate shot; and, on account of their unsaleability in market to the restaurant, from the poaching pot-shot also.

I should, therefore, myself, be strongly inclined to advocate the adoption of one eommon day, and that day the first of October, for the close-time of all our upland game; thc Englisll Snipe alone excepted. Touching the reasons for postponing the day of Woodcock-shooting, a notice will be found in our July number, and an extended discussion in my Field Sports, vol. I. pp. 169 to 200. Of the Quail, in regard to this point, I have said enough here, unless this; that, in my opinion, there is far more need to protect them from the trap during the wintry snows, than from the gun in the early autumn; the latter cannot possibly at any time exterminate the race; the former not only easily may, but actually does all but annihilate the breed, whenever the snow falls and lies deep during any weeks of December, during the whole of which month the pursuit and sale of this charming little bird is legal.

Could I have my way, the elose-time for Quail should end on the last day of September; and the slooting season end on the twenty-fourth day of December; before whieh date snow now rarely lies continuously in New Jersey, Southern New York, or Pennsylvania. Why I would anticipate the termination of the elose-time, in reference to the Ruffed Grouse, I shall state at length, when I come to treat of that noble bird, in our December issue; to which month I have attributed it, because it is then that it is, though in my opinion, it ought not to te, most frequently seen on our tables. While on the topic of preservation, I will mention a fact, which certainly is not widely, mueh less generally known, among farmers; namely, that this merry and domestic little bird is one of his best friends and assistants in the cultivation of his lands. During nine or ten months of the year he subsists entirely on the seeds of miny of the most troublesome and noxious weeds and grasses, which infest the fields, more especially those of the rigrwort, the dock, and the briar. It is believed, I might almost say ascertained, that he never plucks any kind of grain, even his own loved buekwheat when ripe, from the stalk, but only gleans the fillen seeds from the stubbles after harvest, so that while he in nothing deteriorates the harvest to be ingathered, he tends in the highest degree to the preservation of elean and unweeded fields and farms; indeed, when it is taken into consideration that eaeh individual Quail consumes daily nearly two gills of weed-seed, it will be at once eviclent that a few bevies of these little birds, carefully and assiduously preserved on a farm, will do morc toward keeping it free of weeds, than the daily annual labor of a dozen farm-servants. This preservation will not be counteracted or injured by a moderate and judieious use of the gun in the autumnal months; for the bevies need thinning, especially of the cock-birds, which invariably outnmmber the hens, and whieh, if unable to pair, from a want of mates, form into little squads or companies of males, whieh remain barren, and hecome the deadly enemies of the young cocks of the following year, beating them off and dispersing them; though, strange to say, they will themselves never mate again, nor do aught, after remaining unpaired during one season, to propagate their species. The use of the trap, on the contrary, destroying whole bevies at a swoop, where the gun, even in the most skillful hands, rarely much more than decinates them, may, in a single winter's day, if many traps be set, destroy the whole stoeking of a large farm for years, if not forever. I have myself invariably remarked, since my attention was first called to the fact, that those farms which are best stoeked with Quail, are invariably the cleanest of weeds; and a right good sportsman, and good friend of mine, working oll the same base per contra, says that, in driving his 
shooting-cart and dogs through a country, he has never found it worth his while to stop and beat a district full of weedy and dirty farms, as such never contain Quail.

If this may lead our farmers to consider that every live Quail does far more good on the farm, than the shilling earncd by his capture in the omnivorous trap; and thercfore to prohibit thcir sons and farm-boys from exterminating them at thcir utmost need, when food is scarcc, and shclter hard to find, my words will not have bcen altogether wasted, nor my object unattained.

Were I a farmer, I would hang it over my kitchen fireplace, inscribed in goodly capitals_-"Spare the Quail ! If you would have clenn fields and goodly crops, sparc the Quail! So shall you spare your labor."

And now, in a few words, we will on to their nomenclature, their distinctive marks, their regions of inhabitation, seasons, haunts, and habits; and last, not least, how, when, and where lawfully, honorably, sportsmanly, and gnostically, you may and shall, kill them.

I will not, however, here pause long to discuss the point, whether they ought to be termed Quail or Partridge. Scientifically and practically they are neither, but a connecting link between the two subgenera. True Partridge, nor true Quail, very perdix, nor very coturnix, exists at all anywhere in America. Our bird, an intermediate bird betwecn the two, named by the naturalists Ortyx, which is the Greek term for true Quail, is peculiar to America, of which but one species, that before us, is found in the United States, except on the Pacific coast and in California, where there are many other beautiful varieties. Our bird is known overywhere East, and everywhere North-west of Pennsylvania, and in Canada, as the Quail -everywhere South as the Partridgc. In size, plumege, flight, habits, and cry, it more closely resembles the European Quail; in some structural points, especially the shape and solidity of the bill, the European Purtridge. On the whole, I deem it properly termed AMerican QUAIL; but whether of the two it shall bc called, matters little, as no other bird on this continent can clash with it, so long as we avoid the ridicule of calling one bird by two different terms, on the opposite sides of one river-the Delaware. The stupid blunder of calling the Ruffed Grouse, Pheasant, and Purtridgc, in the South and East, is a totally different kind of misnomer; as that bird bears no resemblance, horvever distant, to either of the two spccies, and has a very good English name of his own, videlicet, "Ruffed or Tippeted Grouse," by which alonc he is known to men of brains or of sportsmanship: With regard to our Quail, it is different, as he has no distinctive English name of his own; but is, cren by naturalists, indiscriminately known as Quail and Partridge. The former is certainly the truer appellation, as he approximates more closely to that sub-genus. We wish much that this question could be settled; which we fear, now, that it never can be, from the want of any sporting authority, in the country, to pass judgment. The "Spirit of the Times," though still as well supported and as racy as ever, has, I rcgret to say, ceased to be an authority, and has become a mere arcna wherein for cvery scribbler to discuss and support his own undigested and crudc notions without consideration or examination; and wherein those who know the least, invariably fancying themselves to kllow the most, vituperate with all the spite of pirtisan personality, every pcrson who having learned more by reading, examination of authoritics, and experience than they, ventures to express an opinion differing from their old-time prejudices, and the established misnomers of provincial or sectional vulgarism.

But to resume, the American Quail, or "Partridge of the South, " is too well known throughout the whole of America, from the waters of the Kennebec on the East, and the Grcat Lakes on the North-beyond which latter, except on the South-western peninsula of Canada West, lying between Lakes Erie, St. Clair, and Huron, they are scarccly to be found-is too well known, almost to the cxtremc South, to need description. Thcir beauty, their familiar cry, their domestic habits during the winter, when they become half civilized, feeding in the barn-yards, and often roosting under the cattle-sheds with the poultry, render them familiar to all men, women, boys and fools throughout the regions, which they inhabit. It is stated by ornithologists, that they abound from Nova Scotia and the northern parts of Canada to Florida and the Great Osagc villnges; but this is incorrect, as they rarely are scen eastward of Massachusetts ; never in Nova Scotia, or Canada East; and range so far as Texas, and the edges of the great American salt desert. The adult male bird differs from the hen in having its chaps and a remarkable gorget on the throat and lower meck, pure white, bordered with jetty black; which parts, in the young male and the adult female, are bright reddish-yellow; the upper parts of both are beautifully dashed and freckled with chestnut and mahogany-brown, black, yellow, gray, and pure whitc; the under parts purc white, longitudinally dashed with brownish red, and transversely streaked with black arrow-headed marks. The colors of the male are all brighter, and more definite, than in the female.

Everywhere eastward of the Delawarc the Quail is rcsident, never rambling far from the liaunts in which he is bred. Evcrywhere to the westward he is in the later autumn migratory, moving constantly on foot, and never flying except when flushed or compelled to cross streams and water-courses, from the west eastward; the farther west, the more marked is this peculiarity.

The Quail pairs early in March; begins to lay early in May, in a nest made on the surface of the ground, usually at the bottom of a tussock or tuft of grass, her eggs being pure white, and from ten to thirty-two in number, though about fourteen is probably the avarage of the bevies. The period of incubation is about four weeks, the young birds run the instant they clip the shell, and fly readily before they have been hatched a fortnight. So soon as the first brood is wcll on the wing, the cock takes charge of it, and the hen proceeds to lay and hatch a second, the male bird and first brood remaining in the close vicinity, and the parents, I doubt not, atteuding the labor of incubation and attending the young. This I have long suspected; but I saw so many proofs of it, in company of my friend and fellow sportsman, "Dinks," whilc shooting together near Fort Malden, in Canada West-where we found, in many instances, two distinct bevies of different sizes with a single pair of old birds, when shooting early in September of last year-that we were equally convinced of the truth of the fact, and of the unfitness of the season.

In October, with the exception of a vcry few late broods, they are fit for the gun; and then, while the stubbles are long, and the weeds and grasscs rank, they lie the best and are the least wild on the rving. The early mornings and latc afternoons are the fittest times for finding them, when they arc on the run, and feeding in the edges of wheat and rye stubbles, or buckwheat patches bordering on woodlands. In the middle of the day they either lie up in little brakes and bog-meadows, or bask on sandy banks, and craggy hill-sides, when they are collected into little huddles, and are then difficult to find. As soon as flushed, they pitch into the thickest neighboring covert, whether bog-meadow, briar-patch, cedar-brake, ravine, or rough corn-stubble, they can find, their flight being wild, rapid, and impctuous, but rarely very long, or well sustained. As they unquestionably posscss the mysterious porver, 
whether voluntary or involuntary, of holding in their scent, for a short time after alighting, and are diffieultly found again till they have run, I reeommend it, as by far the better way, to mark them down wcll, and beat for another bevy, until you hear them ealling to eaeh other ; then lose no time in flushing them again, when they are sure to disperse, and you to have sport with them.

Myself, I prefer setters for their pursuit, as more dashing, more enduring, and abler to face briars-others prefer pointers, as steadier on less work, and better able to fag without water. Either, well broke, are good-ill broke, or unbroke, worthless. Still give me setters-Russian or Irish speeially! Quail fly very fast, and strong, espeeially in covert, and require the whole eharge to kill them dead and elean. At cross shots, shoot well ahead; at rising shots, well above; and at straight-away shots, a trifle below your birds; and an oz. $\frac{1}{4}$ of No. 8, early, and of No. 7, late, will fetch them in good style. And so good sport to you, kind reader; for this, if I err not, is doomed to be a erack Quail season.

\section{THE SPECTRE KNIGHT AND HIS LADYE-BRIDE.}

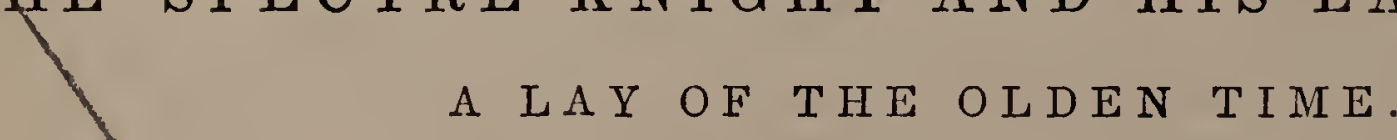

A LAY OF THE OLDEN TIME.

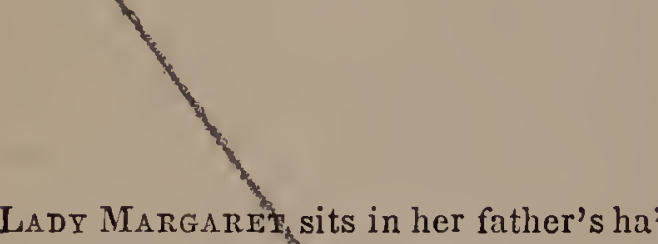

Wi' the tear-drot in her een,

For her lover-knight wis far awa'

In the fields o' Palestine.

Now the rose is fled frne her downy eheek, An' wan is her lily-white land, An' her bonnie blue e'e the tear doth dim, For her knight in the Holy Lund.

His banner it is the Holy Cross, But it gars her greet fu' sair,

As she meekly kneels and his lo'ed name breathes At Our Mother's shrine in prayer.

" $O$, hae ye a care, sweet Mother fair, O'er the lion-hearted king,

But send me baek Sir Filuebrande safe, Abune a' ither thing !"'

'T is Hallowe'en, and twelve lang months Hae i' their turn passed round,

An' 't was Hallowe'en when Sir Hildebrande marched

For Palestine's holy ground.

The castle elock tolls midnight's hour, An' the ladye bethinks her now

Of her lover's words at the trysting-tree-

His fervent and heartfelt vow.

"O, ladye fair," said the gallant Hildebrande,

"When twelve lang months shall fiee,

Come ye then through the mossy glen

Adown by the trysting-tree.

When the wearie year bringsflallowe'en

Ance mair to this lo'ed land,

An' if thou wilt eome at jiridnight's hour

Thou shalt hear of thrne own Hildebrande."

O, the wintry wind blaws sair and chill, An' it whistlesf 'u' mournfully,

As the ladye strolls, at the witehing hour, To the glen adown the lea.

The maidén draws her mantle elose, For the night is dark arr' drear,

An' now that she nears the trysting-tree Ifer heart it quails wi' fear.

O, louder and hoarser blaw's the blast, An' darker grows the sky,

\section{BY FANNY FIELDING.}

An' the clattering tramp of a eourser's hoof Grows nigh, an' yet more nigh

The eoal-blaek steed doth slack his speed An' halt at the ladye's side,

An' a red light gleams in flickering beanss Around her far and wiate.

A mail-clad knight doth now alight, So ghastly pale an' wan

That the ladye gries, wi' tearfu' eyes, " Where is my lover gane!"

A voiee like the hollow, murm'ring wind Replied to the high-born dame-

" $\mathrm{O}$, thy lover sleeps on the battle-field Among the noble slain-

But the soul that vowed to be true to thee Will be true whate'er betide, An' returns from the land of ehivalrie To elaim thee for his bride!"

This said, he stretehed forth his bony hand Te his well-beloved bride,

An' now he mounts the eoal-blaek steed WVi' the ladye by his side.

But hist ! the moor-eoek erows fu' shrill Alang the dreary way,

All' goblin, elf, nor wand'ring ghaist Can face the light o' day.

The phantom steed doth ehamp his bit An' flash his fiery eye

An' away they speed o'er hill an' daleO'er rock an' mountain high !

Lang years hae passed sinee Sir Hildebrandc came Frae the fields o' Palestine,

To claim fair Margaret for his bride But on every Hallowe'en,

When the castle elock tolls midnight's liour, As on that night of yore,

The ladye and knight arc secn to sweep Adown the drearie moor.

The eoal-black steed doth ehamp his bit $\mathrm{An}^{\prime}$ flash his fiery e'e,

But he slaeks his speed at the knight's command As le gains the trysting-tree. 


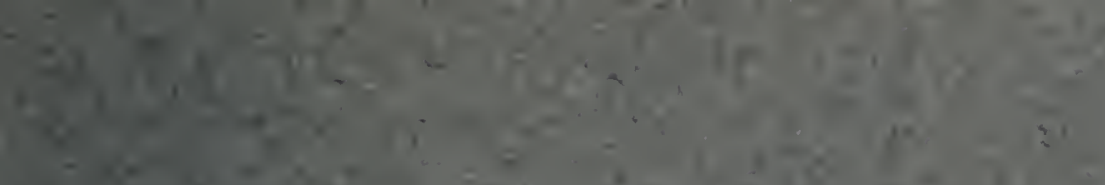

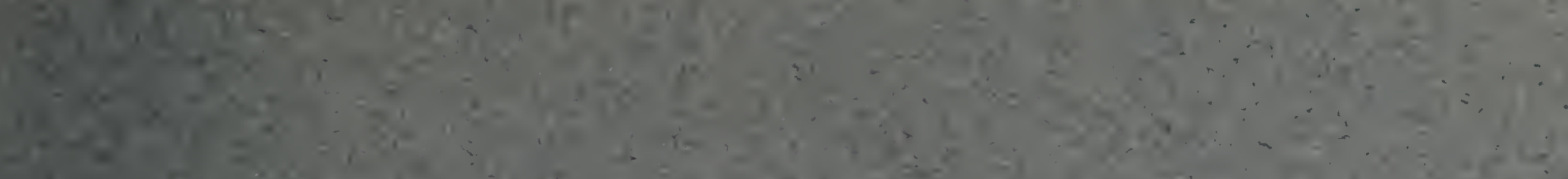

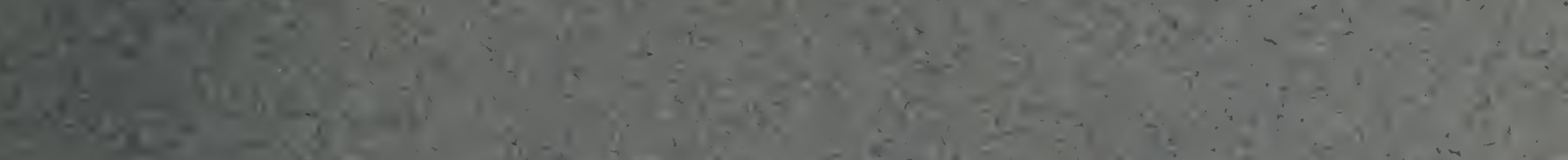

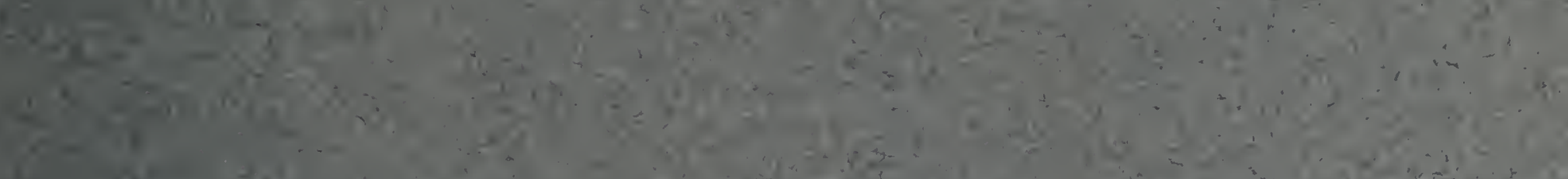

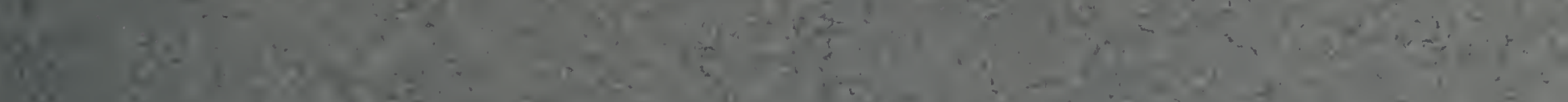

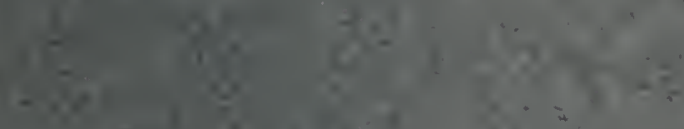

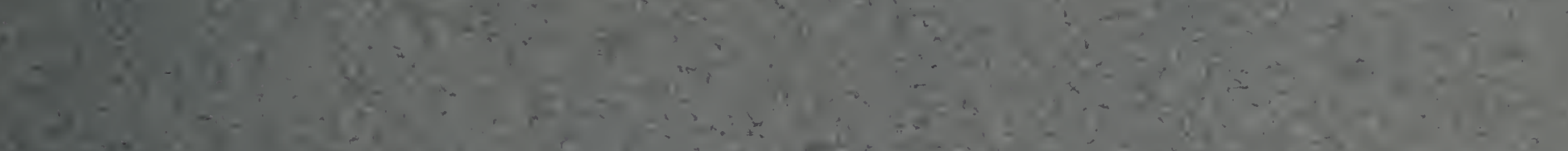

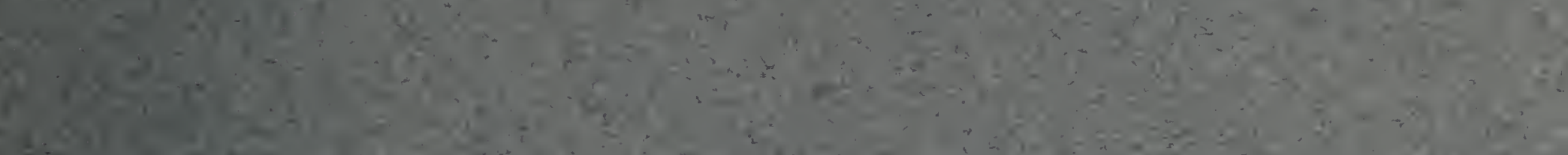

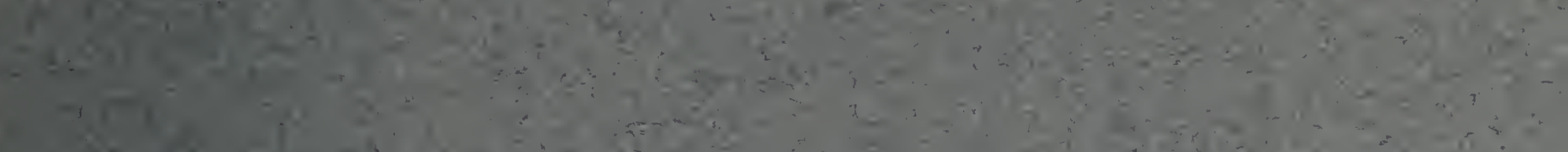

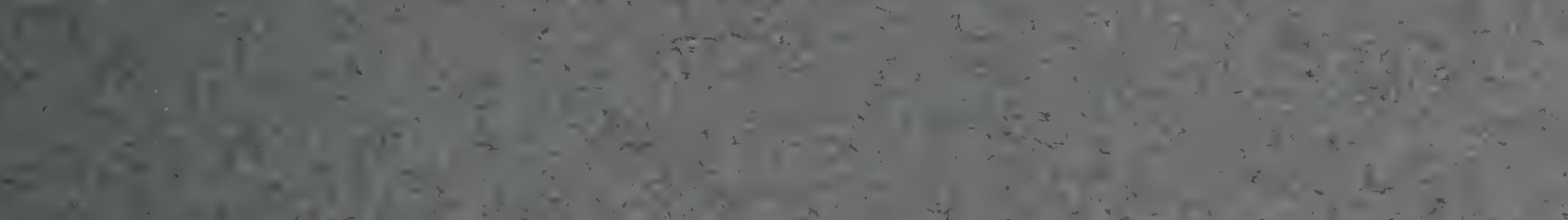

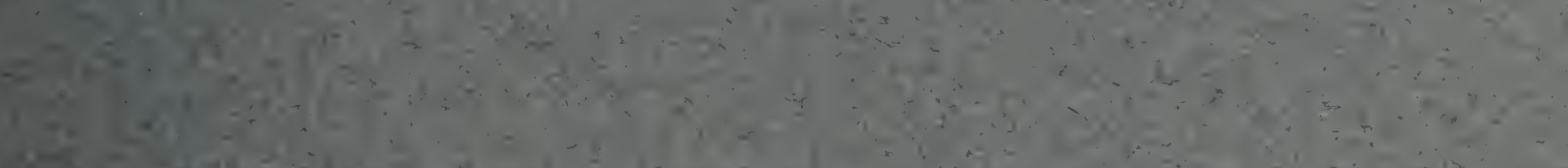

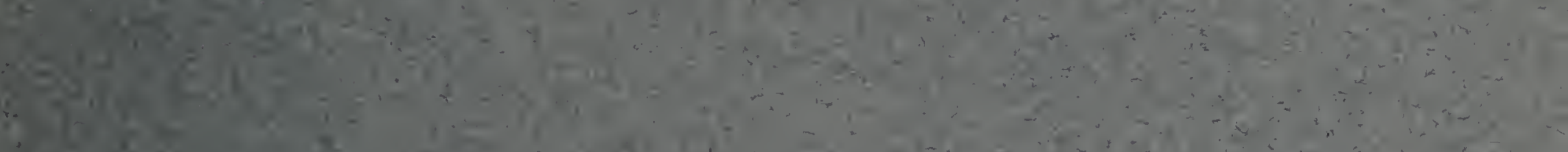

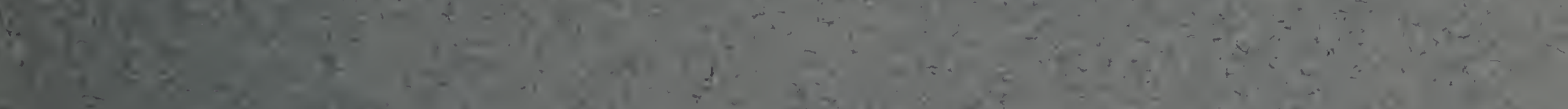

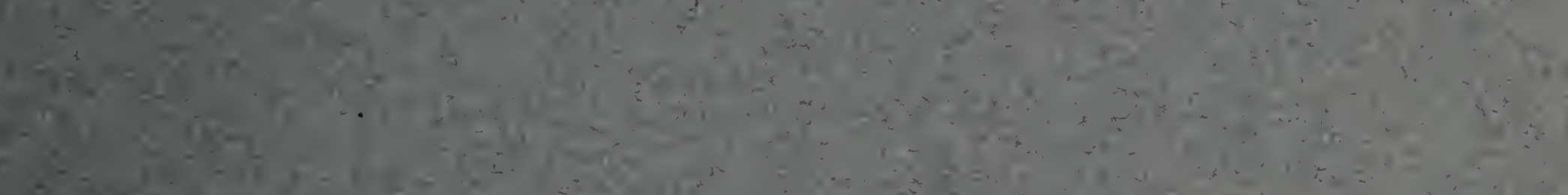

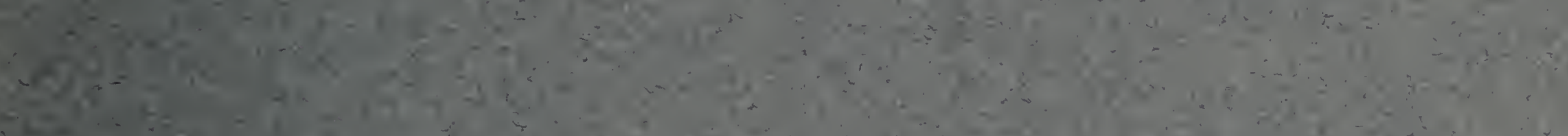

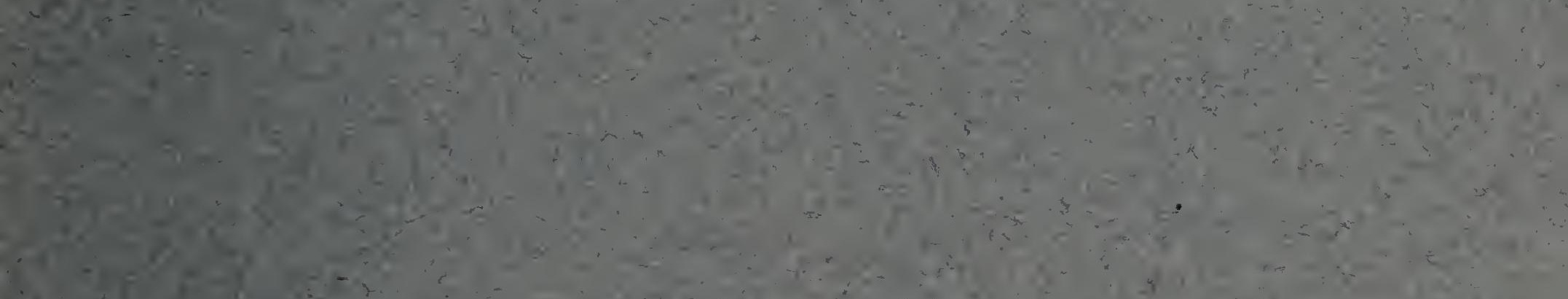

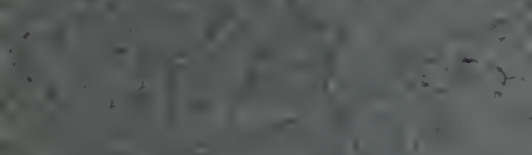

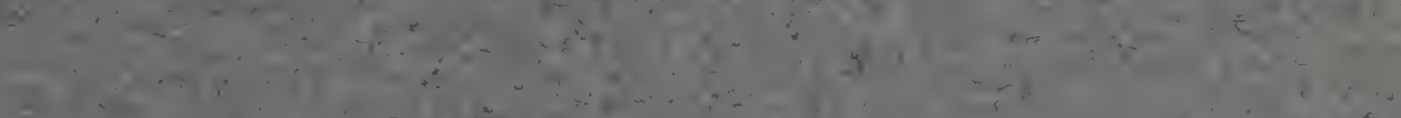

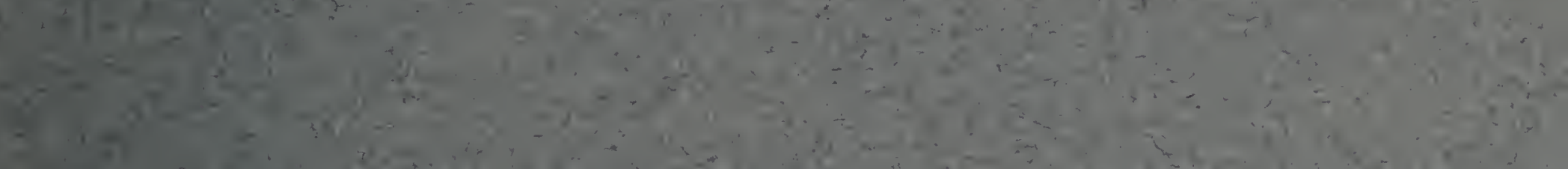
ix

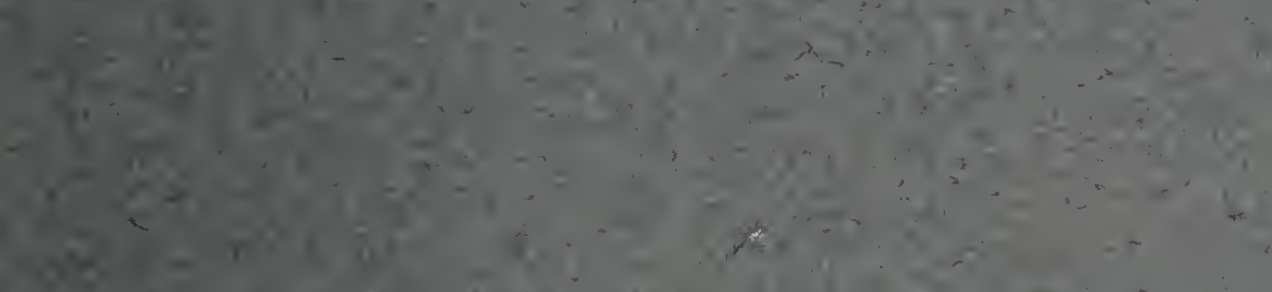

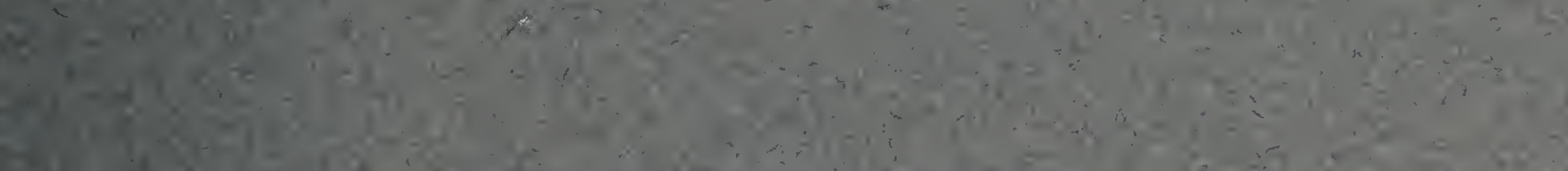

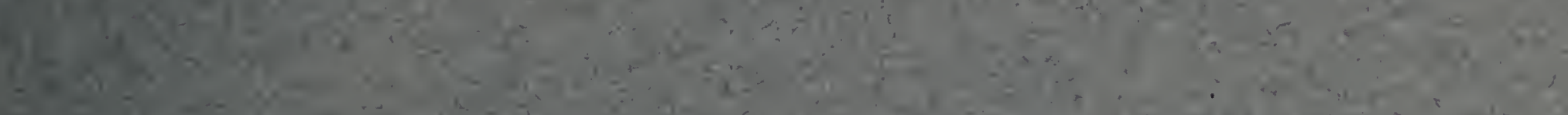

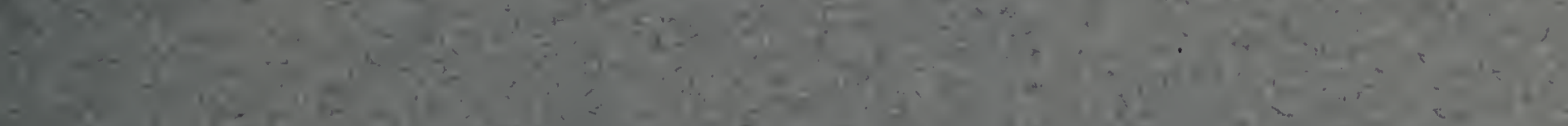

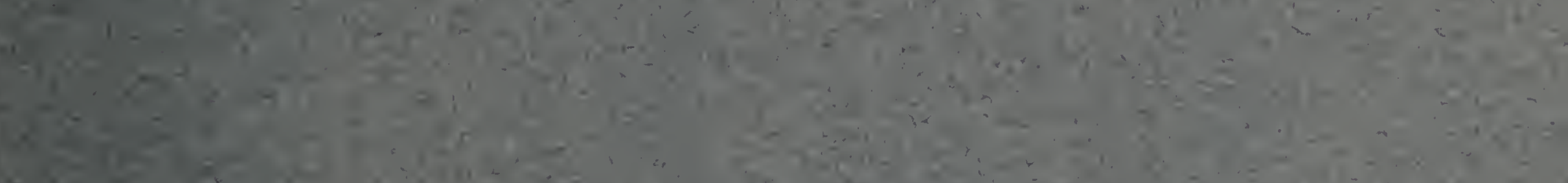

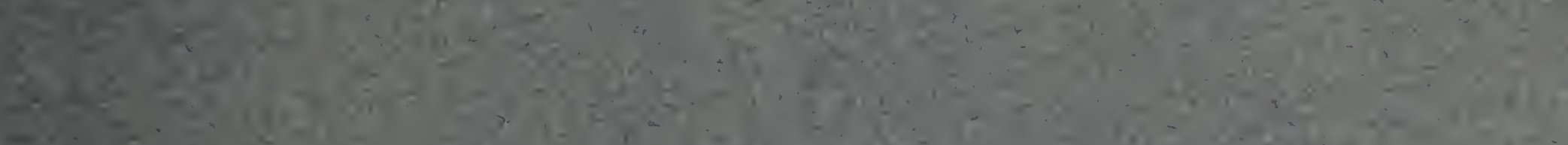

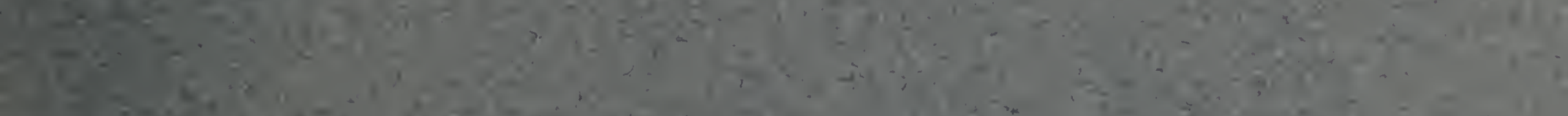

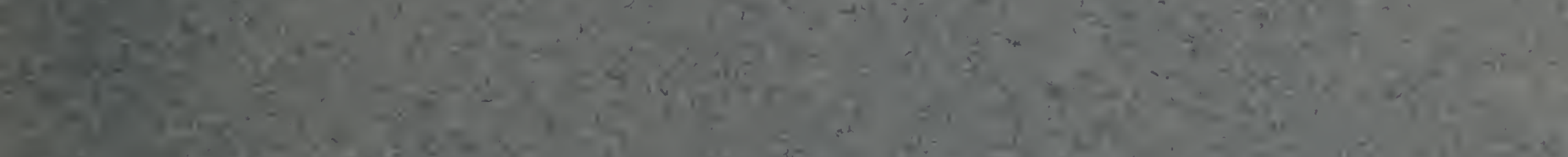

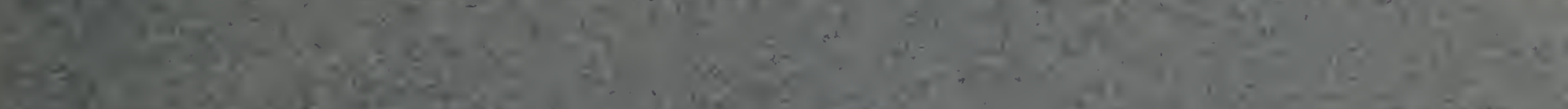

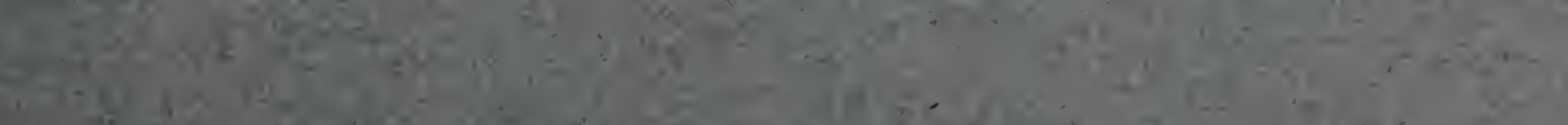

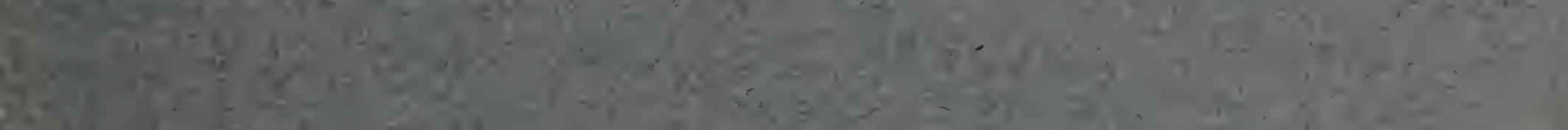

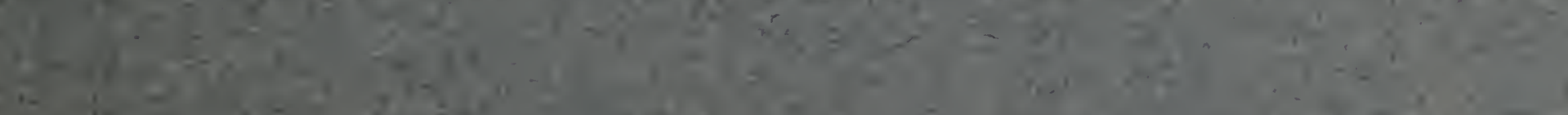




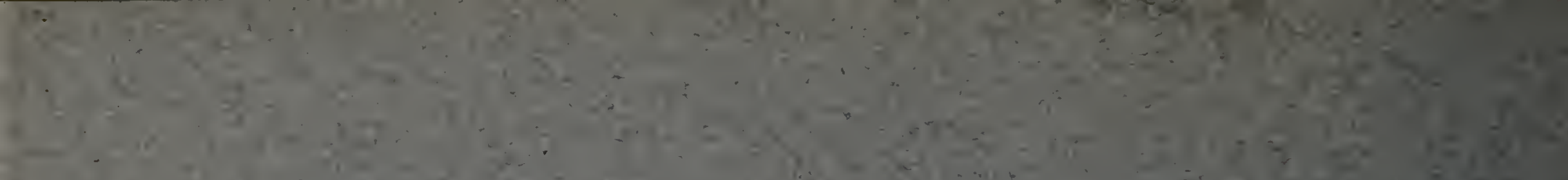

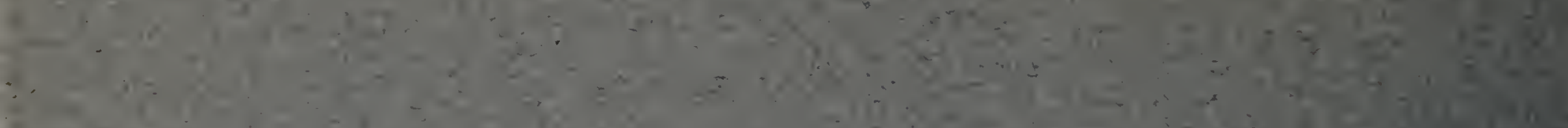

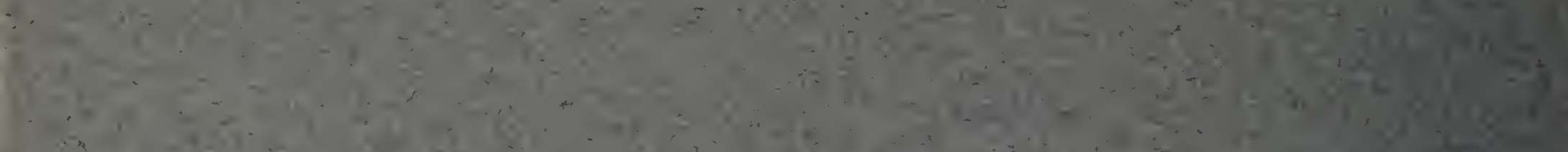

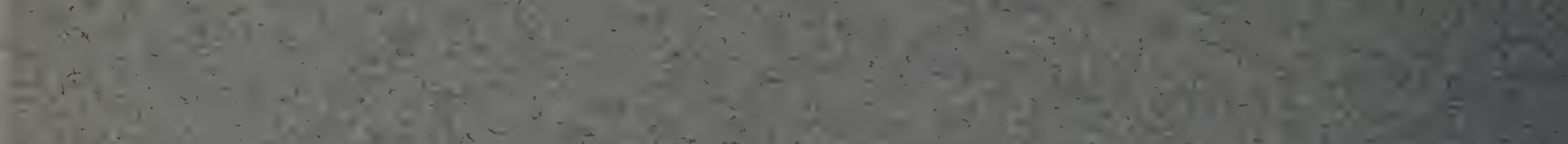

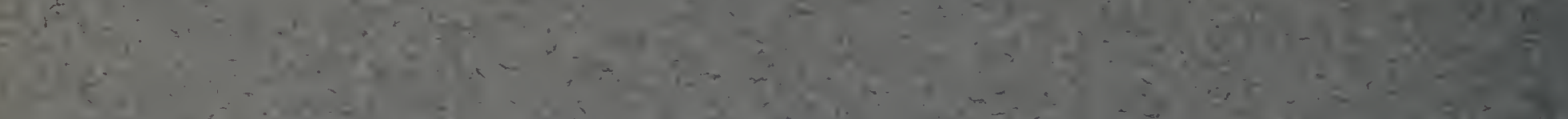

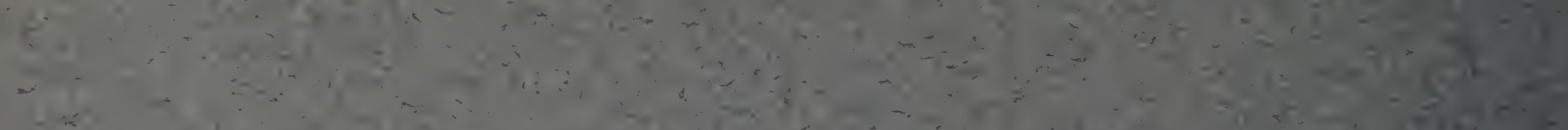

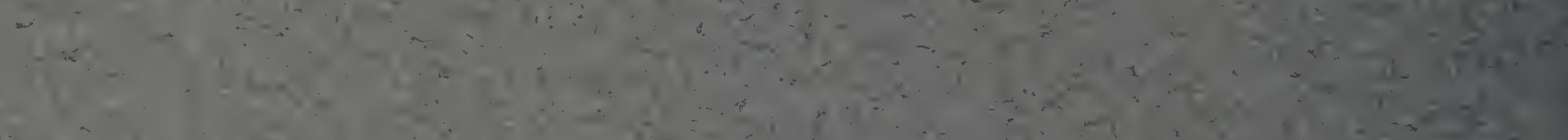

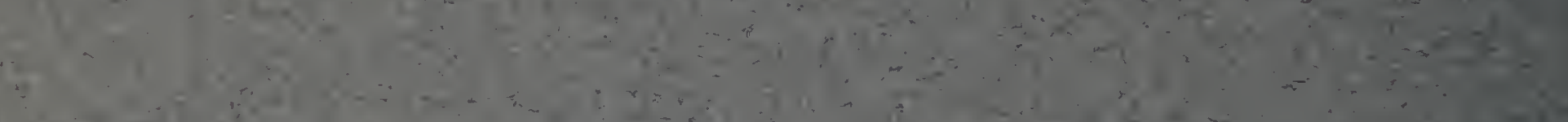

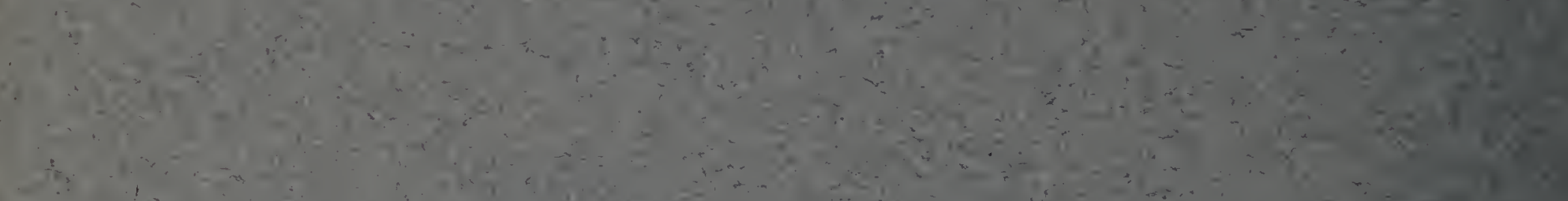

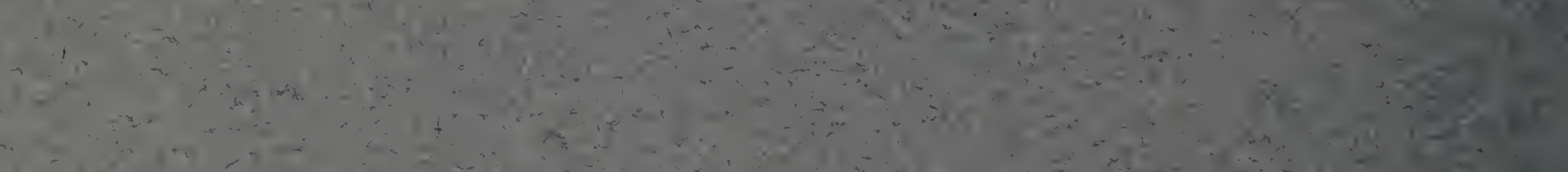

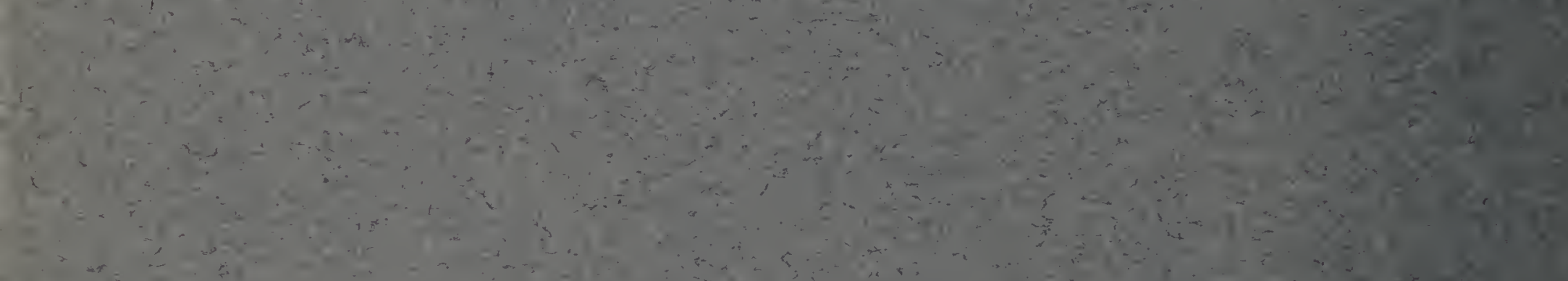

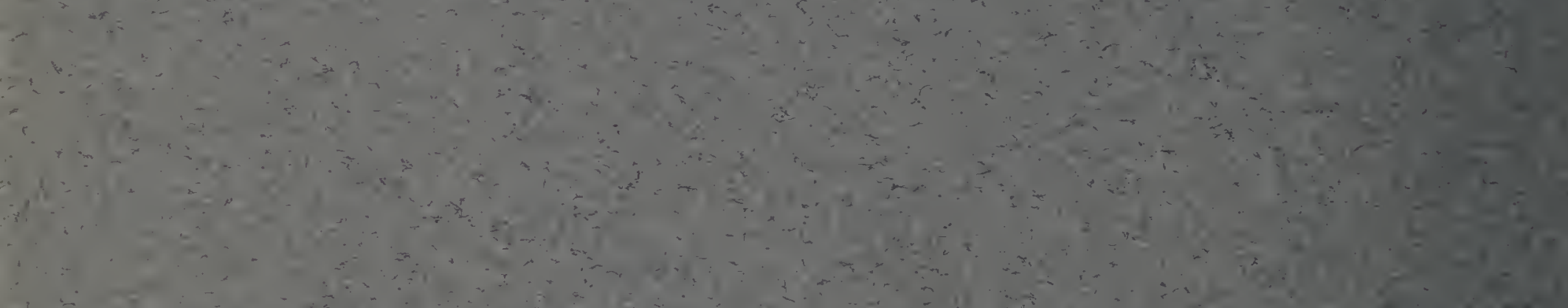
$2+4 x^{2}-1, x+25$

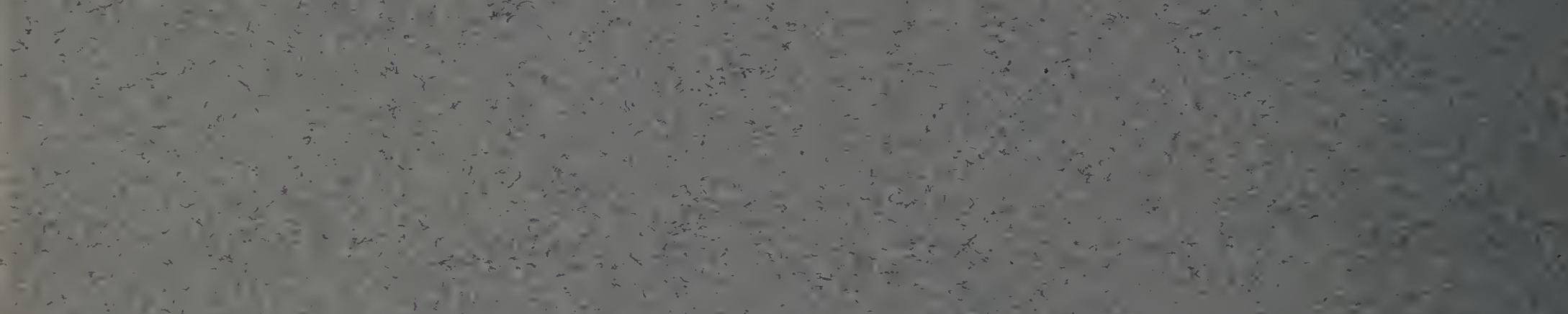
te $\therefore \div$

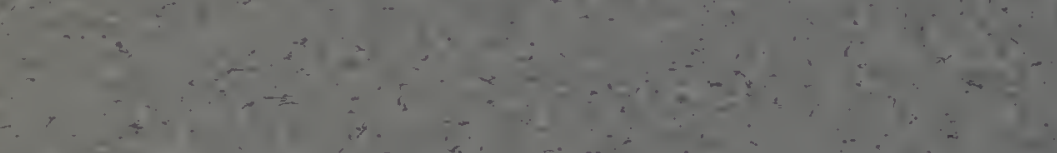

(5)

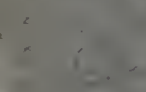
(si

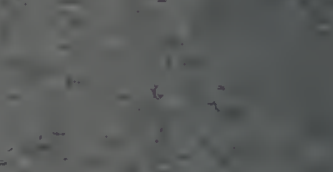
$\left(\begin{array}{ccc}0 \\ 0\end{array}\right.$

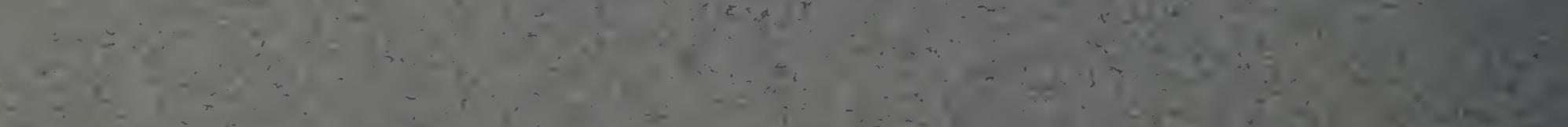

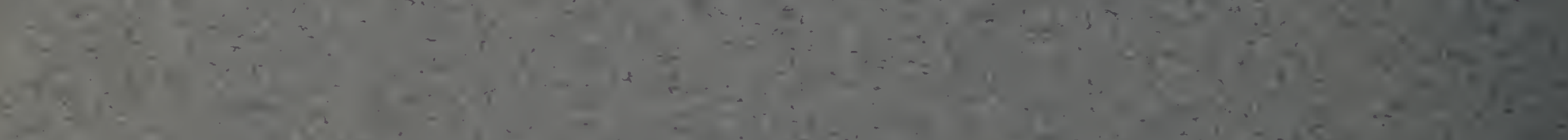

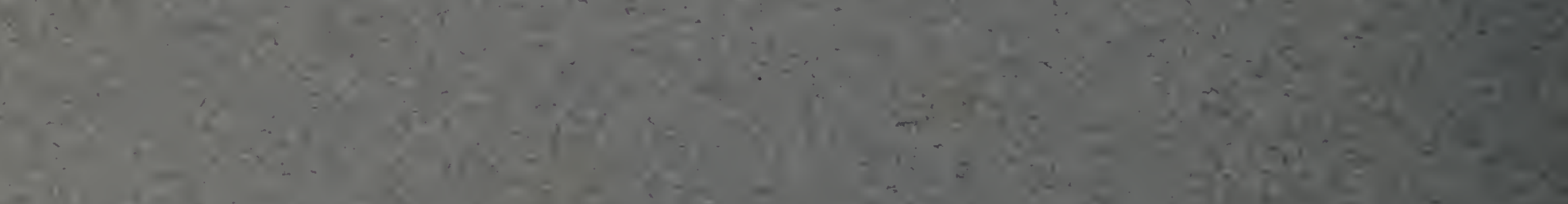
(1) (1) (1) (1) 